\title{
The Aesthetic Significance of Traditional Ethnic Elements in Environmental Design
}

\author{
Guang $\mathrm{Li}^{1}$ \\ ${ }^{1}$ Jilin Agricultural University, School of Humanities, Changchun, Jilin, 130118 \\ hunter2011@foxmail.com
}

Keywords: Traditional Ethnic Element, Environmental Design, Aesthetic Significance

\begin{abstract}
In the modern environmental design, traditional national characteristic elements are widely used. A lot of environmental art designers can blend traditional ethnic elements with modern environmental art perfectly, so that Chinese traditional ethnic characteristic elements can be better heritaged and get better promotion. This paper describes a method for the application of traditional ethnic elements in modern design; provide an effective way for the correct understanding of the national culture and the rational application of traditional ethnic elements and also makes a useful exploration of modern environmental design.
\end{abstract}

\section{Introduction}

Chinese people has created a myriad of material and spiritual civilization in the progress of long history of 5000 years. China is widely recognized as one of the four ancient civilizations, its brilliant history culture of the historical development of the neighboring countries and the world, have a profound impact on the cultural form. These common wealth of human development in the world to make an important contribution to our nation even more development in the architectural design of the most abundant materials and resources [1].

Chinese architectural art has a long history, in the history of world architecture occupies a seat important role, whether it is the royal palace, the wealthy or ordinary garden houses are leading the trend. Fully demonstrated the Chinese nation in terms of architectural art of wisdom and unique aesthetic taste, especially architectural art of ethnic minorities, it is the world building the garden in a wonderful odd Court. However, since the twentieth century, modern Western architectural concept submerged buried in the fine traditions of Chinese national architecture, many excellent traditional architectural arts, especially minority architectural art is slowly dying. People blind pursuit of contemporary architectural design and unique features in the design of the traditional doctrine of many great inventions of architectural, interior design creation will be squeezed, replace, or even the danger of being swallowed. For substances However, they are modern architecture, modern decor of the mother. So, how to inherit the essence of traditional national art and architecture to improve its deficiency is before us is an important issue for each designer.

With the development of arts and culture, especially into this century, mankind increasingly aware ": the more national, the more of the world." The design is based on future-oriented culture and design based on different cultural backgrounds. Different nationalities, different countries have different historical backgrounds and cultural environment, and thus in the design process, increasing the added element of cultural content and to fully reflect the cultural connotation and taste to enhance the cultural value of the works, to ensure its own characteristic work is vital important. Therefore, environmental design in modern China, reflecting the form of traditional Chinese culture and traditional folk architecture still has a strong vitality so make the domestic environment designers have to think about: In the modern environmental design, how will make the integration of modern environmental design with the traditional national characteristics and elements symbols. 


\section{The Meaning of Traditional Ethnic Element}

China is an ancient culture, rich cultural heritage. Traditional ethnic element, it means used in the construction, clothing, paintings and the like some of the imagery, embodied the spirit of traditional Chinese culture, and reflect the national dignity and national interests of images, symbols, or customs, are all characteristic elements of traditional ethnic. Our attention to the unity of opposites, moderation and exquisite harmony of Confucianism Taoism inaction, it belongs to the category of traditional Chinese national characteristics of the element [2].

\section{The Category of Environment Design}

Environmental design is a new comprehensive discipline, is an art form based environment exists, works emphasize interdependence with the environment, the integration of the relationship, emphasizing the expression of artistic ideas author to the material texture, space size, light color, proportion scale and other performance modeling language, so that works and into the atmosphere of the environment among. Including interior decoration, interior design, decoration design, landscape garden, landscape sketch (scene sculpture, landscaping, road), decoration and decoration, urban planning and so on.

\section{The Aesthetic Significance of Traditional Ethnic Elements in Environmental Design}

Our country has a rich traditional architecture, garden art heritage, forming a unique style of traditional culture. Our environmental art designers use modern design interpretation of traditional culture artistic vision, eliminate their bad poise and draw its essence, integration of Western modern environmental art design, creating a modern environmental art works with national traditional culture, so full of unique artistic personality of environmental art and design works remain permanently charm [3].

Traditional ethnic elements give lasting vitality to environmental design. Modern environmental art designers establish creative ideas into the national traditional culture, in environmental art design process, by means of modern design methods, and effective integration of traditional characteristics, geographic characteristics and ethnic characteristics, customs and cultural characteristics of each place, create an environment for development of art, environmental art and design work gives lasting vigor and vitality, the formation of environmental art and design creation model with Chinese characteristics, promote the sustainable development of China's environmental art and design industry.

Traditional ethnic elements enhance the subtle nature of environmental design. China's traditional culture "expensive without saying", that China's traditional culture has a subtle nature, words intended to do endless. Environmental art is both a form of language, but also the emotional language, both concrete and abstract, both determined and uncertain. Therefore, environmental art and design should be moving environment and avoid the proliferation of artistic language too, too intuitive, to make people think of and often generate a lot of nostalgia, have different feelings and different moods and the imagination to create opportunities for everyone to play, this is our country where the subtle nature of strength of traditional culture.

Traditional ethnic elements enhance harmony of environmental design. China's traditional culture, such as "Heaven", "virtual and real," and other concepts, contains sustainable development and harmonious development, scientific development of ideas, people and the environment to emphasize harmony with nature, live in harmony with nature, to heaven together a realm. Of the deteriorating ecological environment designed to warn staff to change the design ideas, to the concept of traditional Chinese culture, learn its inner essence, combined with modern Western design, environmental art design of traditional culture and modern design style design work, to achieve sustainable development for the benefit of mankind. 


\section{Traditional Ethnic Elements and Classical Chinese Culture}

Elaborating on the building in the field of semiotics, the architectural style, materials, use, etc., are reflected from their use abstract functions, while access to the non-cultural implications of architecture, form a similar sign language means systems .

Architectural elements in accordance with the rules of meaning generation combined with each other and transmit visual information to the people. Architectural symbols of the code means the system is composed of many collections and building codes consisting of architectural elements. Its symbol is generated by building codes significance.

Traditional ethnic designs are a strong territorial. In the different regions have different geological climate, environment, customs, history and culture, thus creating different geographical buildings are an obvious sign of culture and style elements in the region. Because traditional ethnic elements semiotics of visual information about the differences architectural culture has a unique sensitivity, so in practice for the architectural creation of modern culture-specific environment will have a more prominent role in guiding [4].

Architectural Design and process designers dialogue with nature. Environment as a precondition for architectural design, architectural design review should be one of their own rationality criteria. Ancient Chinese thinker, founder of Taoism Lao Tzu's "return to basics, in harmony with nature," the idea is rooted in traditional Chinese at all levels. Ancient Chinese philosopher Chuang Tzu Taoism representative, that "Heaven", strongly praise all things natural and orderly. "Heaven and Earth often carry inherent, natural bright sun and the moon men, stars inherent column men, poultry Cape inherent group men, inherent trees stand central." "Zhuangzi • Heaven" in the reflected ideas had a profound influence on future generations are traditional culture is the essence of ancient Chinese thought and culture, and traditional ethnic elements and symbols everywhere in the ground engraved ancient ideological and cultural imprint.

Chinese ancient symbol of their distinctive national elements is unique in the construction technology and artistic history of mankind is a rare treasure. In today's modern design using traditional ethnic elements going bad sperm, get rid of to the right choice, you can achieve a higher level. Traditional ethnic elements which contain the human spirit and artistic charm, as spring water to give a steady stream of modern architects design inspiration and creative passion.

\section{The Innovation of Traditional Ethnic Elements in Modern Architectural Design}

Fusion of traditional ethnic elements with modern architectural design symbols like the relationship between water and ice. Inheritance is the historical process of traditional culture, only inherit and develop history will progress, society was able to develop. Not inherit the traditional culture of its surface, the rough stuff, but the spirit and content of the inherent essence of traditional culture, through space and materials selection and use, showing the ideas of harmony between man and nature living environment. The traditional culture and traditional ethnic elements inherit the ancient ideological constraints and breakthrough innovation on its basis and is an inevitable trend of modern architectural design direction and development, it will achieve the highest level of integration of traditional and modern [5].

Many architects on how to apply to the traditional elements of the symbol of modern architecture design on this issue put forward their point of view. Renowned architect Mr. Wu Liangyong has raised the viewpoint of "abstract inheritance" and he advocated the best parts of traditional architectural design principles and basic theory (not counted philosophy, principles, etc.) to be developed. Both in the use of traditional elements in the creation of symbolic practice, the traditional architectural image of the most distinctive part can be extracted; then through abstraction, concentration, improve as a motif, to be innovative, creative design forms to inspire the creation of the current off. Both overall demand in the creation, some quite similar, does not exclude a certain extent, certain details of the shape. Of course, even so, also after re-creation, but not completely copy the. Therefore, learn traditional ethnic element symbols, such as the construction of components, 
space, mood, materials, technology and other elements, through abstraction and transformation forms a symbol, and then apply it to modern architecture has become a tradition of architectural design approach, will provide a new way for the traditional national symbols of elements in modern buildings a new expression. Moderately accurate symbol of traditional ethnic elements Yiyun developed by modern science and technology, a variety of building materials and design techniques creatively diverse expression. The use of traditional national symbols continuation of regional architectural elements context, to suit the local history, culture, cultural customs, we are the right way to use the traditional national element symbols and innovation.

\section{Conclusion}

The reasonable combination of Chinese traditional ethnic elements with modern environmental design should be the the natural reflection of traditional spiritual core in the modern environment design and it is not the stiff copy. It is the produced inspiretion of modern environmental art designer for traditional ethnic elements and in line with the psychological needs of people's hearts. It is a natural expression of deep emotion for traditional national characteristic elements. Modern environmental art designers need to use creative thinking to restructure and rebuild the traditional ethnic elements in the carrier of modern environment in order to design a modern art both with distinctive traditional ethic elements, but also with people's aesthetic psychology, so that our modern environment design business can be flourishing.

\section{References}

[1] Y.X., Duan, Reconstruction of Chinese traditional culture symbols in product design, J. Packaging Engineering, 1 (2012) 34-35.

[2] X.Hu, Liming Bei’s architectural thinking and creative approach, J. Chinese and Foreign Construction, 6 (2011) 11-12.

[3] Z.H, Zhang, The application of national culture in modern packaging design, J. Packaging Engineering, 2(2005) 11-15.

[4] J.H. Xu, Reconstruction of Chinese traditional culture symbols in product design, J. Packaging Engineering, 1 (2007) 54-59.

[5] M.H.Zhou, The eco-analytical of local ecological architecture and interior design, J. Interior Design and Decoration, 11 (2002) 11-17. 